\title{
Pengenalan Alternatif Usaha Bagi Santri Pondok Pesantren Salaf Al Anwar Bogangin Melalui Pelatihan Teknologi Pengolahan Hasil Ternak
}

\author{
Afduha Nurus Syamsi*1, Lis Safitri², Hermawan Setyo Widodo ${ }^{3}$, Dewi Puspita Candrasari ${ }^{4}$ \\ 1,2,3,4Jurusan Peternakan Fakultas Peternakan, Universitas Jenderal Soedirman, Indonesia \\ *e-mail: afduha.nurus.syamsi@unsoed.ac.id¹, lis.safitri@unsoed.ac.id², hsw@unsoed.ac.id³, \\ dewipuspita.chandra@unsoed.ac.id ${ }^{4}$
}

\begin{abstract}
Abstrak
Pondok Pesantren Al Anwar Bogangin merupakan pondok pesantren salafyang masih menerapkan model pembelajaran tradisional. Santri tidak mendapatkan pendidikan formal, sehingga perlu diberikan pelatihan keterampilan. Tujuan kegiatan ini adalah untuk memberikan pelatihan keterampilan teknologi pengolahan hasil ternak sebagai alternatif usaha santri dimasa mendatang. Metode yang digunakan yaitu sosialisasi, penyuluhan dan pelatihan, serta praktek, diakhiri dengan evaluasi. Hasil kegiatan menunjukkan bahwa santri sebagai kelompok sasaran mampu membuat produk yang serupa dengan model percontohan yang diberikan tim penyuluh. Hasil evaluasi menunjukkan bahwa kegiatan pelatihan mampu meningkatkan pengetahuan dan keterampilan peserta dengan hasil peningkatan nilai sebesar 57.43\% pada kelompok santri putra dan peningkatan sebesar $60 \%$ pada santri putri pada nilai post test dibandingkan nilai pre test. Sebanyak 100\% peserta menyatakan kegiatan menarik dan 68\% menyatakan berminat untuk membuat usaha dengan bahan serupa materi pelatihan. Berdasarkan hasil kegiatan dapat disimpulkan bahwa pengenalan teknologi pengolahan hasil ternak sebagai alternatif usaha Santri Pondok Pesantern Salaf Al Anwar berhasil dilaksanakan dengan menarik, meningkatkan pengetahuan dan keterampilan, serta menimbulkan minat sebagian besar santri untuk berwirausaha pada bidang serupa.
\end{abstract}

Kata kunci: keterampilan, pelatihan, pondok pesantren salaf, teknologi pengolahan hasil ternak

\begin{abstract}
Al Anwar is a salaf Islamic boarding school that still applies the traditional learning model. Santri does not receive a formal education, so skills training is necessary. The purpose of this activity is to provide training in animal product processing technology skills as an alternative to the santri business in the future. The method used is socialization, counseling, and training, as well as practice, ending with evaluation. The results showed that the santri as the target group were able to make a product similar to the pilot model provided by the extension team. The results of the evaluation showed that the training activities were able to increase the knowledge and skills of the participants with the result of an increase in the value of 57.43\% in the male santri group and an increase of $60 \%$ for female students in the post-test scores compared to the pretest scores. As many as $100 \%$ of participants stated that the activity was interesting and $68 \%$ stated that they were interested to starting a business with similar materials of training. Based on the results of the activity, it can be concluded that the introduction of animal product processing technology skills as an alternative business to the Salaf Islamic Boarding School of Al Anwar was successfully implemented by attracting, increasing knowledge and skills, as well as arousing the interest of most students to become entrepreneurs in similar fields.
\end{abstract}

Keywords: animal product processing technology, salaf islamic boarding school, skills, training

\section{PENDAHULUAN}

Pondok pesantren merupakan lembaga pendidikan Islam tertua di Indonesia, yang telah berdiri sejak abad ke-15 dan masih bertahan sampai saat ini. Sebagian besar di antaranya mempertahankan diri sambil melakukan penyesuaian dengan madrasah dan sekolah umum, hanya sebagian kecil saja pondok pesantren yang masih mempertahankan sistem pendidikan tradisional yang disebut pondok pesantren salaf [1]. Pesantren salaf sendiri merupakan pesantren tradisional yang mempertahankan pengajaran kitab-kitab Islam klasik (salaf) sebagai inti pendidikan. Pondok pesantren jenis ini mengadopsi sistem kelas (madrasi) hanya untuk memudahkan pengajaran, sementara pengajaran dilakukan melalui sistem sorogan, dan 
bandongan, tidak mengenalkan pengetahuan umum, tidak terintegrasi dengan madrasah, mempertahankan terjemah dengan pegon, dan kyai berperan sebagai pusat keilmuan [2].

Salah satu pondok pesantren salaf di Kabupaten Banyumas adalah Pondok Pesantren AlAnwar, Sumpiuh. Pondok pesantren tersebut murni menyelenggarakan pendidikan agama tanpa pendidikan formal. Pondok Pesantren Al-Anwar telah berdiri sejak 1925 dan memiliki sekitar 80 orang santri putra dan putri dengan rentang usia 10-23 tahun. Santri pada umumnya berasal dari keluarga pra sejahtera. Setiap santri menjalankan pendidikan pondok hingga 7 tahun dan hampir semua santri tidak bersekolah formal, sebagai implikasi dari sitem salaf yang diterapakan. Kegiatan utama pondok berupa pengajian yang dilaksanakan pada pagi, sore, dan malam hari. Waktu siang hari, dikhususkan bagi siswa untuk melaksanakan usaha pondok dan usaha pribadi santri. Hal tersebut di lakukan dalam upaya pengelolaan pondok untuk melaksanakan proses pembelajaran dan penghidupan santri.

Santri putri umunya mengelola usaha pembuatan tempe milik pondok pesantren, sementara santri putra memiliki kegiatan yang beragam. Sebagian besar santri bekerja kepada masyarakat menjadi buruh tani, kuli bangunan, karyawan toko, dan mengelola pengairan desa. Sebagian kecil santri mengelola sawah milik kyai. Pendidikan keterampilan bagi para santri di Pondok Pesantren Al-Anwar belum dibekali secara mumpuni, khususnya bagi santri putra. Minimnya pendidikan keterampilan ditambah tidak memiliki pendidikan formal tinggi, sulit bagi para santri untuk mendapatkan pekerjaan yang layak setelah lulus dari pesantren. Jalan ekonomi yang paling mungkin ditempuh mereka adalah keterampilan berwirausaha [3].

Pendekatan keterampilan yang dapat dikenalkan pada santri yaitu teknologi pengolahan produk hasil ternak. Produk diversifikasi hasil ternak saat ini cukup berkembang baik. Economic rate pada usaha pengolahan hasil ternak juga cukup baik. Hal ini dibuktikan dari tumbuh dan kembangnya usaha penjualan produk olahan peternakan seperti milk shake, telur gulung, sosis, nugget, yoghurt dan lain sebagainya [4]. Perkembangan usaha pengolahan produk hasil ternak didukung dengan peningkatan pendapatan dan berimplikasi pada perubahan gaya hidup masyarakat. Perkembangan tersebut juga didukung dengan kemudahan mendapat bahan baku seperti telur ayam, telur bebek, daging, dan susu di masyarakat [5]. Berdasarkan pada potensi tersebut, tujuan dilakukanya pemberdayaan ini adalah untuk memberikan pelatihan keterampilan teknologi pengolahan hasil ternak sebagai alternatif usaha santri dimasa mendatang.

\section{METODE}

\subsection{Kerangka Pemecahan Masalah}

Keterampilan merupakan suatu keahlian yang dapat dilakukan karena pengetahuan dan adanya kebiasaan pengulangan pada kegiatan atau aktivitas yang sama. Pada dasarnya setiap manusia memiliki kesempatan dan peluang dalam mengembangkan keterampilan. Hal tersebut juga berlaku untuk santri pondok pesantren salaf Al-Anwar. Permasalah utama yang diupayakan untuk ditangani oleh tim pemberdayaan yaitu meminimalisir santri untuk bekerja pada pekerjaan teknis yang tidak memberikan bekal keterampilan. Santri diarahkan untuk membaca dan menciptakan peluang usaha terutama pada produk-produk yang mudah didapatkan dan dekat dengan masyarakat.

Produk peternakan seperti susu dan telur merupakan produk yang umum dikenal oleh masyarakat dan mudah di dapat disekitar pondok. Oleh karena itu, pelatihan keterampilan akan diarahkan pada pengolahan produk susu dan telur. Pendekatan teknologi perlu diberikan oleh santri dalam mengolah produk susu dan telur. Tujuanya untuk meningkatkan daya guna dan nilai jual dari produk tersebut. Teknologi pengolahan susu yang dapat diterapkan yaitu pembuatan es krim. Berlainan dengan susu, pedekatan teknologi pada telur adalah preservasi menggunakan garam, menjadi telur asin. Materi yang digunakan adalah telur bebek, karena produk telur asin yang lebih akrab di masyarakat adalah telur asin.

Santri diberikan pengetahuan mengenai teknologi pengolahan hasil ternak, baik alat, bahan, dan prosedur pengolahan. Produk-produk yang dibutuhkan dalam pelatihan 
keterampilan adalah materi pengolahan es krim dan telur asin (power point dan leaflet), serta peralatan dasar penerapan teknologi dalam pengolahan susu dan telur. Keterampilan dasar teknologi pengolahan produk telur dan susu selanjutnya menjadi modal utama bagi santri untuk memulai usaha. Bagan alir pemecahan masalah dapat dijelaskan pada Gambar 1.

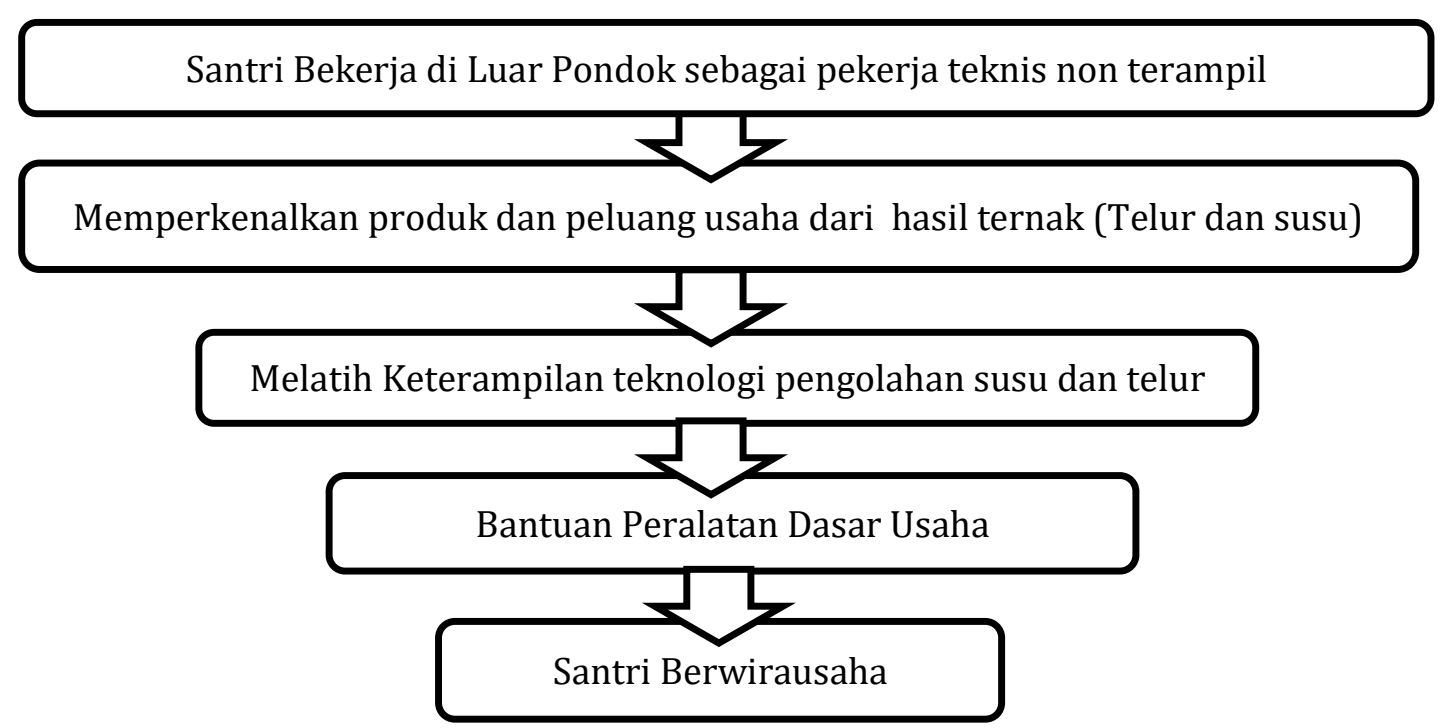

Gambar 1. Bagan Alur Pemecahan Masalah Peningkatan Keterampilan Wirausaha Santri Pondok Pesantren Salaf Al-Anwar Melalui Teknologi Pengolahan Hasil Ternak

\subsection{Metode}

Metode yang digunakan yaitu sosialisasi, penyuluhan dan pelatihan, serta praktek, diakhiri dengan evaluasi. Penyuluhan dilakukan dengan maksud untuk meningkatkan pengetahuan para peserta, serta alih pengetahuan dari penyuluh ke peserta. Metode yang tepat adalah dengan ceramah dan diskusi. Sementara itu untuk meningkatkan keterampilan para peserta, dilakukan demplot dengan pendampingan oleh tim penyuluh untuk pembuatan es krim dan telur asin. Alur kerja kegiatan pelatihan dijelaskan pada diagram Gambar 2.

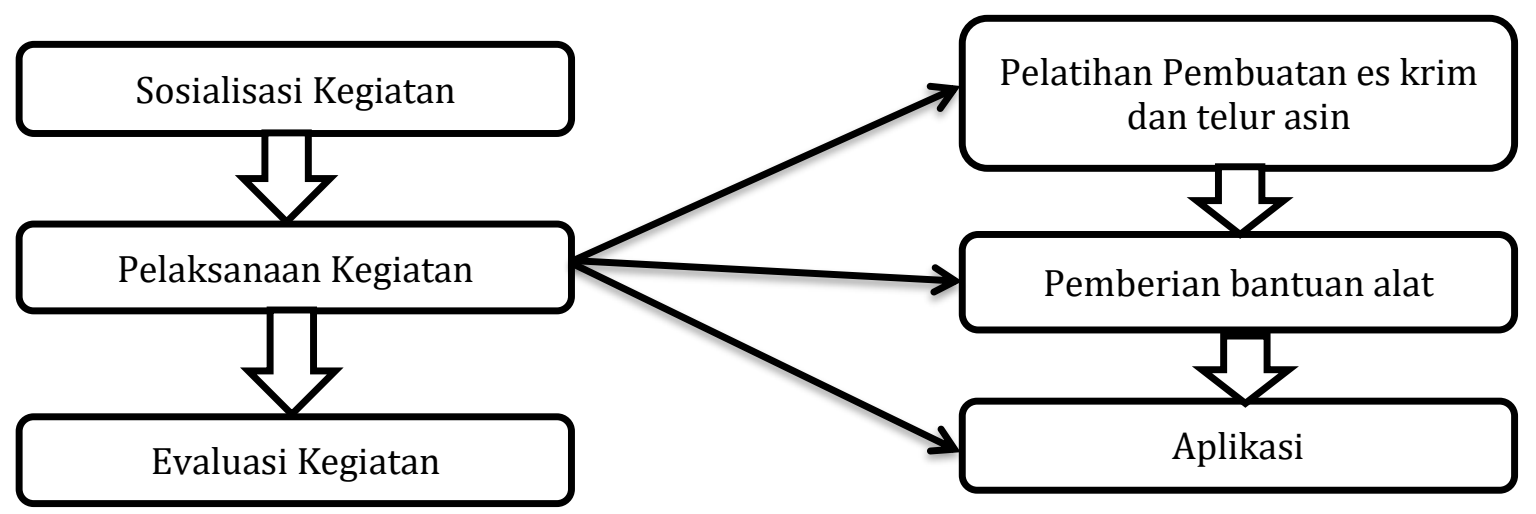

Gambar 2. Diagram Alir Metode Penerapan Teknologi Pengolahan Hasil Ternak

Evaluasi dilaksanakan melalui kontrol dan pengamatan secara langsung pada aktivitas santri pasca pelatihan. Evaluasi juga akan dilaksanakan secara lisan maupun tertulis pada setiap kegiatan. Tujuanya adalah untuk mengetahui tingkat keberhasilan sosialisasi dan pelatihan yang dilakukan oleh tim penyuluh melalui pre dan pos test. Indikator yang digunakan adalah persentase peningkatan nilai dari pre-test dibanding post-test. Semakin tinggi nilai post test 
maka semakin baik materi yang diserap oleh para peserta. Hasil evaluasi akan dibahas secara deskriptif dengan pengembangan pembahasan melalui perbandingan berbagai studi literatur.

\section{HASIL DAN PEMBAHASAN}

\subsection{Sosialisasi Kegiatan}

Sosialisasi dilakukan sebelum serangkaian pelatihan dan pendampingan teknologi pengolahan hasil ternak di Pondok Pesantren Al Anwar Bogangin dilaksanakan. Sosialisasi dilakukan dalam bentuk paparan materi, diskusi dan ajakan secara persuasif. Materi berkaitan dengan tujuan dan rencana program serta gambaran teknologi pengolahan produk ternak yang akan diterapkan. Materi teknologi pengolahan yang diberikan adalah pembuatan es krim berbahan dasar susu dan pengasinan telur bebek.

Sosialisasi penting untuk dilaksanakan dalam rangka membangun komitmen dan partisipasi aktif melalui penjelasan deskripsi kegiatan serta tujuan dan manfaatnya [6]. Partisipasi dan komitmen peserta dalam pelaksanaan penyuluhan sangat penting dalam upaya pencapaian tujuan kegiatan. Proses sosialisasi umumnya dilakukan paling awal sebelum serangkaian kegiatan inti dilaksanakan, pada tahapan ini juga dapat dilakukan penilaian kompetensi sasaran [7]. Penilaian dilakukan dengan melaksanakan pre test dengan soal-soal yang berkaitan dengan materi-materi kegiatan dalam hal ini adalah menguji seberapa jauh pengetahuan peserta dalam pembuatan es krim dan telur asin. Hasil pre test selanjutnya dapat dijadikan landasan oleh tim penyuluh untuk menetukan materi dengan metode yang disesuaikan dengan standar kompetensi sasaran. Pre test dilakukan pada dua kelompok santri dengan materi pelatihan yang berbeda, hasil pre test dapat dilihat pada Gambar 3.

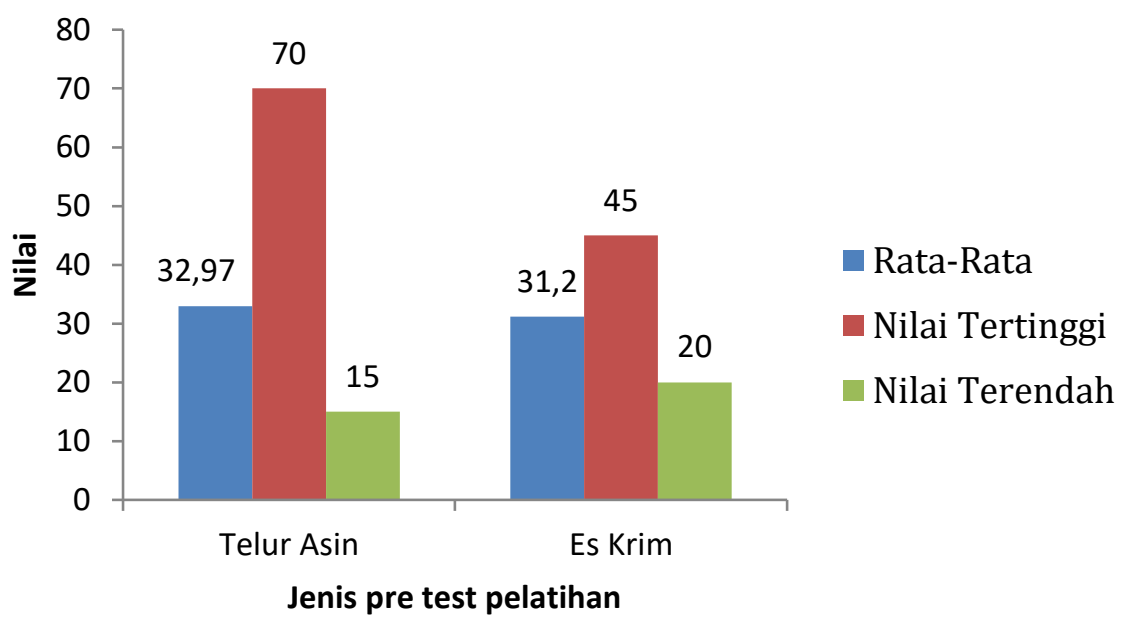

Gambar 3. Hasil pre test tentang teknologi pengolahan hasil ternak

Gambar 3 menunjukan bahwa sebagian besar peserta tidak mengetahui dengan baik terkait teknologi pembuatan telur asin ataupun es krim. Nilai rata-rata santri putra adalah 32,97 dan santri putri adalah 31,2, sedangkan nilai tertinggi dan terendah santri putra yaitu 70 dan 15, santri putri yaitu 45 dan 20. Santri putra memiliki rataan nilai dan capaian nilai pre test lebih tinggi dibandingkan santri putri. Hal ini tidak terkait dengan perbedaan gender tetapi karena materi pembuatan telur asin cukup umum diketahui dan lebih mudah. Hasil pre test dapat dijadikan dasar dan pemetaan bagi tim penyuluh untuk menentukan kedalaman materi yang akan diberikan pada sesi pelatihan atau pembuatan demplot [8].

\subsection{Penyuluhan dan Pembuatan Demplot}

Kegiatan ini diawali dengan pembagian leaflet tentang teknologi pembuatan telur asin dan es krim. Leaflet merupakan media tercetak yang efektif dalam aspek penyuluhan pengetahuan dan keterampilan, serta pada sasaran individu ataupun berkelompok [9]. Leaflet berisi tentang 
penjelasan produk, tata cara pembuatan, alat dan bahan yang dibutuhkan, serta perhitungan ekonomi sederhana. Peserta diberikan wawasan materi secara runut dan menjelaskan pokokpokok penyuluhan teknologi pengolahan hasil ternak yang sebelumnya telah tertuang dalam pertanyaan pre test. Proses penyuluhan dilakukan dua arah dengan memberikan kesempatan peserta bertanya, berargumen serta berdiskusi. Proses komunikasi dua arah akan lebih efektif, karena memberikan kesempatan peserta untuk berbagi pengalaman pribadi terkait materi penyuluhan [8]. Gambaran kegiatan penyuluhan dapat dilihat pada Gambar 4.
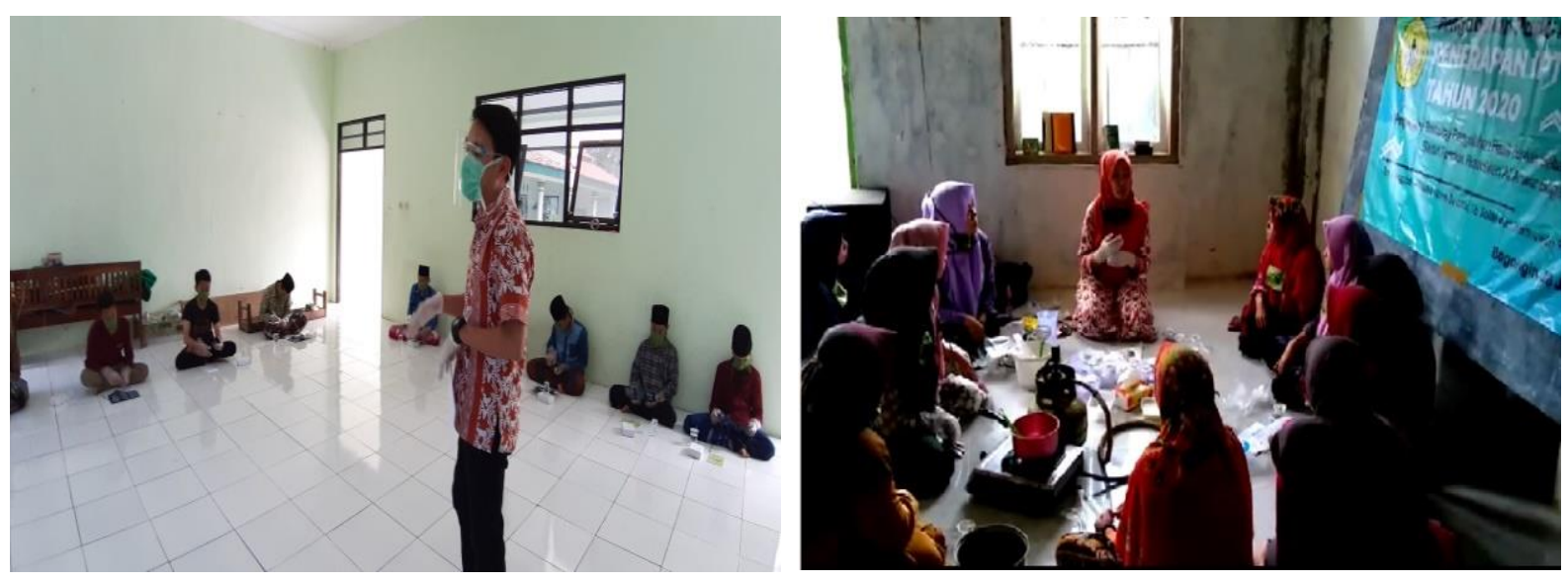

Gambar 4. Penjelasan materi penyuluhan oleh tim penyuluh kepada peserta

Peserta santri putra mendapatkan materi mengenai pembuatan telur asin, sedangkan santri putri mengenai pembuatan es krim. Materi yang diberikan meliputi peralatan, bahan, prosedur pembuatan, dan manfaat dari penerapan teknologi pengolahan tersebut terhadap produk peternakan serta potensinya sebagai usaha sampingan. Penjelasan potensi usaha didukung dengan contoh perhitungan sederhana modal, pendapatan dan keuntungan yang sederhana. Materi yang diberikan oleh penyuluh akan lebih optimal jika dikaitkan dengan halhal yang mudah ditemukan disekitar kelompok sasaran, selain itu gambaran kerja sederhana dalam mengaplikasikan teknologi yang diberikan juga penting untuk diperhatikan [10]. Oleh karena itu, selain pembagian leaflet dan penjelasan lisan, juga dilakukan pelatihan langsung atau pembuatan demplot.

Pembuatan demplot merupakan salah satu metode penyuluhan yang cukup efektif bagi kelompok sasaran. Pengetahuan dan skill peserta akan lebih terasah dengan praktik langsung pada. teknologi yang diajarkan [11]. Hal sejalan dilakukan dalam proses penyuluhan ini, Peserta mempraktekan langsung pembuatan telur asin dan atau es krim. Masing-masing kelompok dibagi lagi menjadi 3 sub kelompok untuk membuat materi produk penyuluhan. Tim penyuluh memberikan instruksi dan mengarahkan masing-masing sub kelompok untuk membuat produk sesuai dengan petunjuk yang telah diberikan. Berkenaan dengan produk telur asin dan es krim yang membutuhkan waktu cukup lama untuk dapat dikonsumsi, maka tim penyuluh telah membawakan produk setengah jadi dan produk jadi untuk diberikan ke peserta. Hal ini dilakukan untuk memberikan gambaran yang riil kepada peserta mengenai produk yang akan dihasilkan. Gambaran kegiatan praktik pembuatan produk dapat dilihat pada Gambar 5.

Output yang dihasilkan dari kegiatan ini adalah produk pengolahan hasil ternak berupa telur asin dan es krim. Produk yang dihasilkan pada masing-masing sub kelompok juga telah sesuai dan menyerupai contoh yang diberikan oleh tim penyuluh. Masing-masing peserta diminta untuk mencicipi produk yang dihasilkan untuk dilakukan perbandingan dengan produk yang umum ada di pasar. Sebanyak $89 \%$ persen peserta meyakini bahwa produk yang dihasilkan akan mampu bersaing dengan produk yang telah ada di pasaran. Hal ini di dasari atas tampilan fisik, rasa dan harga dasar dari produk yang dihasilkan dalam penyuluhan. 

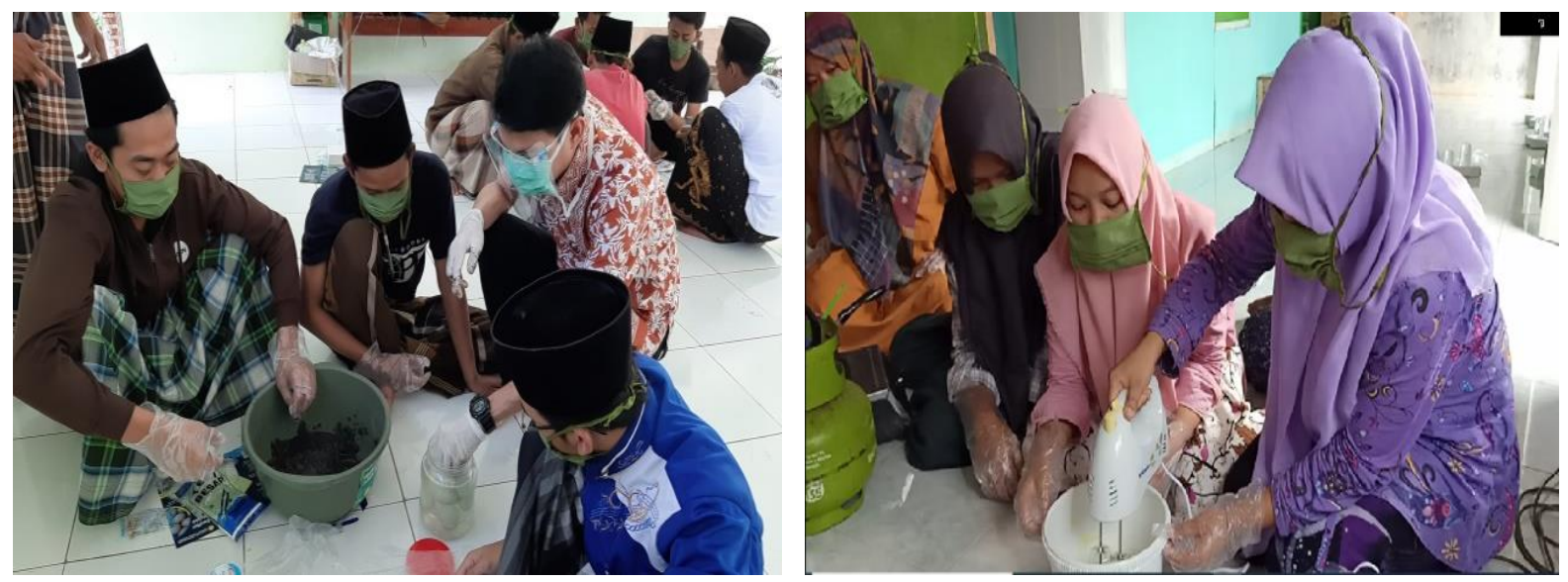

Gambar 5. Pembuatan demplot telur asin dan es krim

\subsection{Evaluasi Pelatihan}

Pelaksanaan evaluasi dilaksanakan setelah serangkaian inti penyuluhan selesai. Fokus utama evaluasi bagi penyuluh yaitu mengevaluasi koordinasi antar anggota penyuluh dalam pelaksanaan kajian lapang dan pembahasan masalah yang menjadi dasar pembuatan materi program penyuluhan, sedangkan bagi sasaran penyuluhan, yaitu mengevaluasi seberapa jauh materi yang disuluhkan dapat dimengerti oleh sasaran penyuluhan. Pelaksanaan evaluasi dengan cara membandingkan tingkat pengetahuan, sebelum dan sesudah dilaksanakan penyuluhan. Apabila ada perubahan pengetahuan, kearah yang lebih baik, berarti kegiatan penyuluhan dapat diterima dengan baik [10].

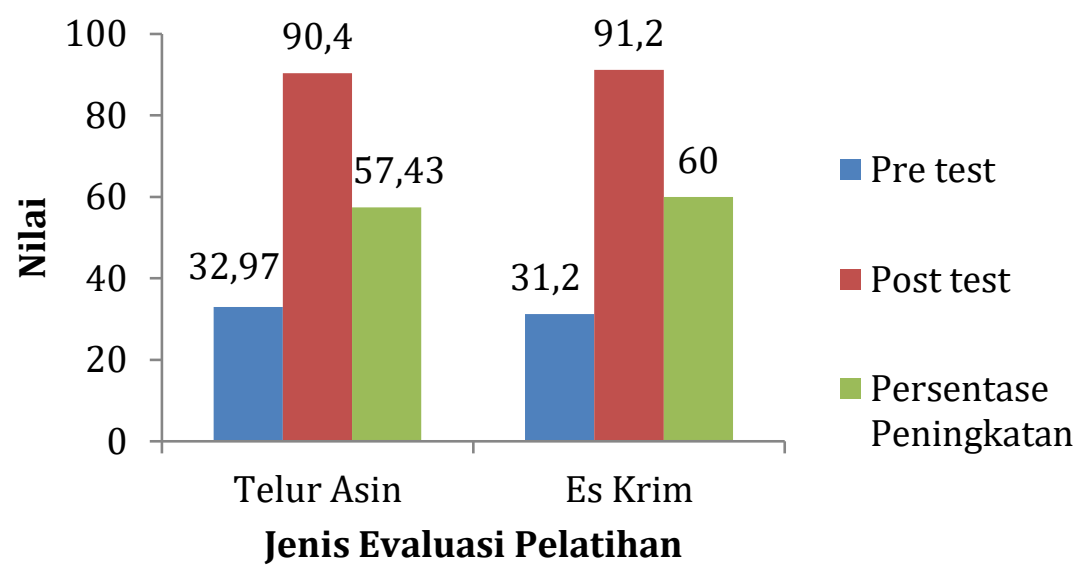

Gambar 6. Evaluasi kegiatan penyuluhan dan pembuatan demplot

Kegiatan evaluasi dilakukan dengan memberikan soal post test yang serupa dengan soal pre test pada peserta. Peserta diminta untuk mengerjakan secara mandiri dan jujur. Hasil evaluasi (Gambar 6) menunjukkan bahwa terjadi peningkatan nilai baik pada kelompok santri putra ataupun santri putri. Kelompok santri putra (penyuluhan telur asin) mendapatkan rataan nilai sebesar 90,4 dan mengalami peningkatan sebesar 57.43\% dibandingkan dengan nilai pre test. Kelompok putri (penyuluhan es krim) mendapatkan rataan nilai sebesar 91,2 dan mengalami peningkatan sebesar $60 \%$ dibandingkan dengan nilai pre test. Peningkatan rataan nilai pada santri putri lebih tinggi dibandingkan dengan santri putra, namun demikian secara keseluruhan evaluasi menunjukkan bahwa pemahaman peserta terhadap teknologi pengolahan hasil ternak (telur asin dan atau es krim) mengalami peningkatan.

Selain melaksanakan post test, tim penyuluh juga melakukan survey mengenai daya tarik penyuluhan dan minat peserta untuk merencanakan usaha pembuatan telur asin ataupun es 
krim. Pelaksanaan evaluasi kegiatan berdasarkan tingkat kepuasan sasaran merupakan hal yang penting untuk diketahui. Hasil evaluasi ini dapat dijadikan dasar dalam pelaksanaan kegiatan berikutnya atau lainya dalam hal penerapan materi juga metode penyuluhan [12]. Hasil survey kegiatan ini menunjukkan bahwa $100 \%$ peserta menyatakan kegiatan penyuluhan menarik untuk diikuti (Gambar 7). Peserta mengungkapkan bahwa banyak manfaat yang didapatkan selama penyuluhan dilaksanakan. Peserta juga mendapatkan tambahan pengetahuan serta pengalaman. Hasil survey juga menunjukan bahwa sekitar $68 \%$ peserta menyatakan berminat untuk menjalankan usaha pengolahan hasil ternak, $27 \%$ ragu-ragu dan $5 \%$ tidak berminat.
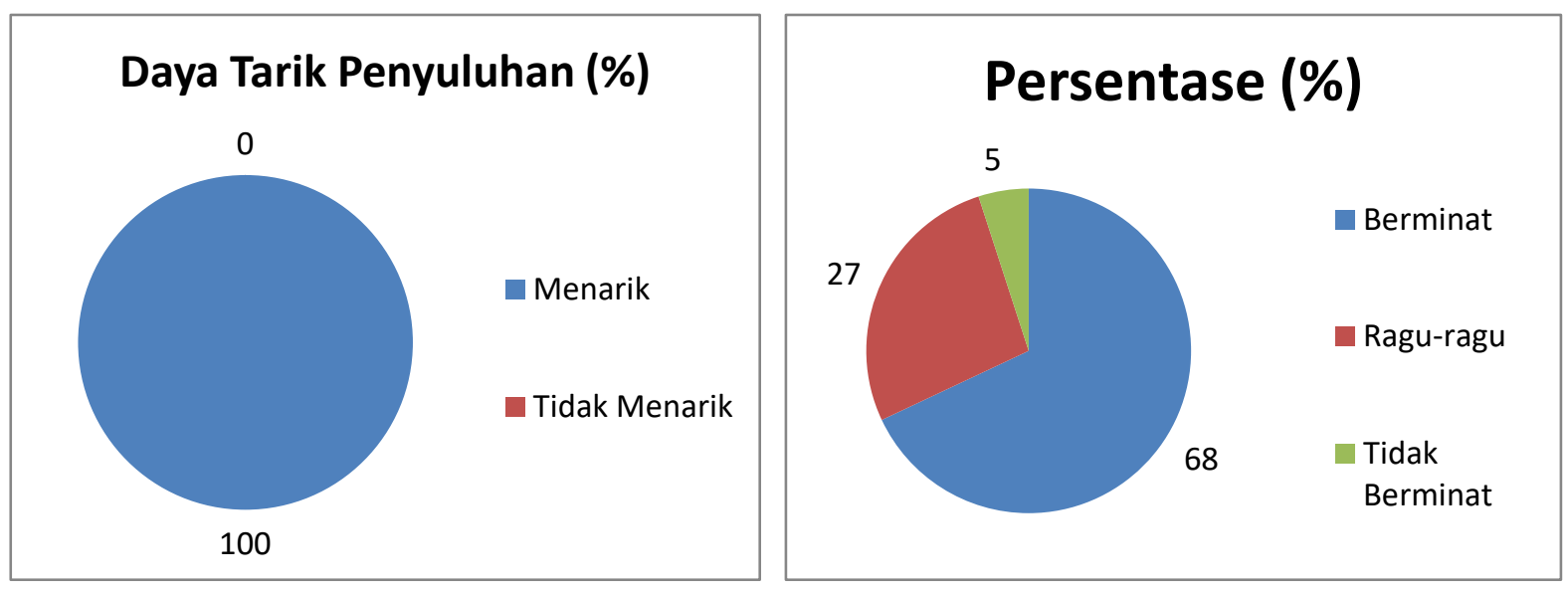

Gambar 7. Hasil survey mengenai daya tarik penyuluhan dan minat peserta dalam menjalankan usaha pengolahan hasil ternak

Gambar 6 dan 7 juga memberikan gambaran bahwa pelaksanaan kegiatan pengabdian kepada masyarakat ini telah sesuai dengan tujuan yang direncanakan. Peningkatan pengetahuan dan minat peserta untuk melakukan usaha pembuatan es krim dan telur asin merupakan indikator yang selaras dengan tujuan. Hasil survey mengenai daya tarik penyuluhan juga membuktikan bahwa kegiatan ini telah sukses dan mampu diterima oleh sasaran. Menurut [13], manfaat kegiatan pengabdian masyarakat dapat diterima paling tidak kepada kelompok sasaran dan tim pelaksana pengabdian. Manfaat utama dari kegiatan ini yaitu skill pembuatan telur asin dan es krim yang diterima langsung oleh sasaran (santri), sedangkan manfaat lainnya diterima oleh pondok pesantren berupa peningkatan kompetensi santri dan peluang usaha yang dapat dijalankan dalam masa mendatang. Selain itu, manfaat yang didapatkan oleh tim pengabdi yaitu mendapatkan wadah untuk mentransfer ilmu pengetahuan dan teknologi serta memperluas hubungan Universitas Jenderal Soedirman dengan institusi dan atau organisasi masyarakat.

\section{KESIMPULAN}

Berdasarkan hasil kegiatan dapat disimpulkan bahwa pengenalan teknologi pengolahan hasil ternak sebagai alternatif usaha Santri Pondok Pesantern Salaf Al Anwar berhasil dilaksanakan dengan menarik, meningkatkan pengetahuan dan keterampilan, serta menimbulkan minat sebagian besar santri untuk berwirausaha pada bidang serupa.

\section{UCAPAN TERIMA KASIH}

Ucapan terimakasih disampaikan kepada Lembaga Penelitian dan Pengabdian Masyarakat (LPPM) Universitas Jenderal Soedirman yang telah membiyayai sepenuhnya kegiatan ini melalui dana Dipa BLU Pengabdian pada Masyarakat (PPM) Program Penerapan Ipteks tahun 2020. 


\section{DAFTAR PUSTAKA}

[1] L. Safitri, "Perkembangan Pendidikan Islam di Indonesia dan Australia," J. M. (et.al), Islam Kontemporer di Indonesia dan Australia, pp. 394-407, PPIM UIN Jakarta dan Australia Global Alumni. Jakarta, 2017.

[2] M. Fahmi, "Mengenal Tipologi dan Kehidupan Pesantren," Syaikhuna, vol. 6, no. 02, pp. 301$319,2015$.

[3] L. Safitri, L. dan A. Y. Prasetiawan, "Tipologi dan Pemetaan Potensi Pondok Pesantren di Kabupaten Banyumas", Laporan Penelitian : Universiras Jenderal Soedirman, (Tidak dipublikasi), 2019.

[4] A. Yuniastuti, N. Setiati dan R. Susanti, "Pengembangan Olahan Hasil Ternak Melalui Diversifikasi Produk Berbahan Dasar Susu di Kelurahan Cepoko Gunungpati Semarang," Rekayasa, vol. 15, no. 1, pp. 11-16, 2017

[5] H. Iskandar dan Nuhung, "Potensi Dan Peluang Pengembangan Pengolahan Dan Pemasaran Hasil Peternakan," Seminar Nasional Teknologi Peternakan dan Veteriner, Litbang Pertanian, 2001.

[6] S. Rumangkit, "Pengaruh Sosialisasi Organisasi pada Komitmen Afektif yang Dimediasi oleh Kesesuaian Nilai," Jurnal Bisnis Darmajaya, vol. 2, no. 01, pp. 34-56, 2016.

[7] R. D. H. Windriyati, L. Tikafebianti dan G. Anggraeni, "Pembuatan Pestisida Nabati Pada Kelompok Tani Wanita Sejahteradi Desa Sikapat," DINAMISIA, vol. 4, no. 4, pp. 635-642, 2020.

[8] P. Soediarto, T. Y. Astuti dan A. N. Syamsi, "Peningkatan Kualitas Susu di Kelompok Peternak Sapi Perah 'Andini Lestari' Melalui Perbaikan Sanitasi Kandang dan Higiene Pemerahan," Prosiding Seminar Nasional Pengembangan Sumber Daya Perdesaan dan Kearifan Lokal Berkelanjutan IX, LPPM Unsoed : Purwokerto, 2019.

[9] S. Padmowihardjo, "Metode Penyuluhan Pertanian," Universitas Terbuka: Jakarta, 2000.

[10] L. Setiana, "Tekhnik Penyuluhan dan Pemberdayaan Masyarakat," Ghalia Indonesia: Jakarta, 2005.

[11] P. Soediarto, T. Y. Astuti, A. N. Syamsi dan H. S. Widodo, "Penerapan Prosedur Higiene Pemerahan Sebagai Bagian dari Good Dairy Farming Practise di Kelompok Peternak Sapi Perah Tirto Margo Utomo Limpakuwus," Prosiding Seminar Nasional Pengembangan Sumber Daya Perdesaan dan Kearifan Lokal Berkelanjutan VIII, LPPM Unsoed: Purwokerto, 2018.

[12] T. Y. Astuti, P. Soediarto, A. Rosyad dan A. N. Syamsi, "Peningkatan Produktivitas Kambing Perah dengan Pemanfaatan Teknologi Hijauan Pakan," Prosiding Seminar Nasional Pengembangan Sumber Daya Perdesaan dan Kearifan Lokal Berkelanjutan VII, LPPM Unsoed: Purwokerto, 2017.

[13] C. I. Asmarawati, "Pembinaan Masyarakat Tentang Komersialisasi dan Sterilisasi Industri pada Pengolahan Abon Ikan Tongkol," Jurnal Pengabdian Masyarakat Indonesia (JPMI), vol. 1, no. 1, pp. 31-35, 2021. 